Perceptual and Motor Skills, 1991, 73, 77-78. (C) Perceptual and Motor Skills 1991

\title{
EFFECT OF NUMBERS VS PICTURES ON PERCEIVED EFFECTIVENESS OF A PUBLIC SAFETY AWARENESS ADVERTISEMENT ${ }^{1}$
}

\author{
STANLEY BOCHNIAK AND H. BRUCE LAMMERS \\ Department of Marketing \\ California State University, Northridge
}

\begin{abstract}
Summary.-In a $2 \times 2$ completely randomized factorial experiment, 24 women and 16 men rated the perceived effectiveness of an earthquake preparedness advertisement which contained either a picture or no picture of prior earthquake damage and contained either statistics or no statistics on likelihood of an earthquake. A main effect for superiority of the picture was found. The presence of statistics had no main or interactive effects on the perceived effectiveness of the advertisement.
\end{abstract}

Some research in consumer psychology suggests that advertisements which contain numbers and statistics may be perceived as more utilitarian and rational than advertisements which are less number-oriented $(1,3)$. On the other hand, advertisements which contain pictures may have a greater emotional effect than number-based presentations (3). The present study was undertaken to extend research on the differential effectiveness of "numbers vs pictures" to a public safety awareness campaign issue replete with both statistical data and emotional reactions-earthquakes in California.

Subjects ( 24 women and 16 men, median age $=24$ years) were randomly assigned to the cells of a 2 (picture vs no picture) $\times 2$ (statistics vs no statistics) completely randomized factorial design. The subjects, who were conveniently selected, were students from the CSU Northridge campus (70\%) and nonstudents from nearby communities in Ventura County, CA (30\%). Subjects were shown an advertisement containing the following banner copy: California is earthquake country. . Be prepared!. . Study the section in your phone book on bow to prepare for a major earthquake. For subjects in the statistics condition, the advertisement also included the following information from the California Department of Conservation (4): There is a 60\% chance of an earthquake measuring at least 7.5 striking southern California within the next 30 years. For subjects in the picture conditions, the advertisement included a photograph of residential dwellings severely damaged in the 1971 Sylmar earthquake. After examining the advertisement, subjects rated the extent to which the advertisement would motivate them to prepare for a major earthquake ("strongly ineffective": 1 ; "strongly effective": 5).

'This paper is based upon a study completed by the first author in partial fulfillment of the requirements for his marketing research course. Please address correspondence to $\mathrm{H}$. Bruce Lammers, Dept. of Marketing, California State University, Northridge, CA 91330. Bitnet: RCCW005@CALSTATE. 
The perceived effectiveness ratings were higher for the advertisements containing the photograph of the earthquake damage than for the advertisements with no photograph $\left(M_{\text {picture }}=3.3, S D=1.2\right.$ vs $M_{\text {no pirture }}=2.4, S D=.9$; $F_{1,36}=7.98, p=.008$ ). This picture-superiority effect on perceived advertising effectiveness is consistent with the picture-superiority effect found on consumer memory variables (2). The manipulation of earthquake statistics in the advertisement had neither a main nor an interactive effect on the perceived effectiveness of the advertisement. Perhaps the statistics were already so well known and stored in memory prior to the experiment that they were being inferred and used even in the conditions without statistics. On the other hand, perhaps consumers simply tend to perceive that statistics in advertisements are one-sided and ought to be processed with a healthy degree of distrust (5). The usual caveats regarding the external validity of a laboratory-like experiment of this kind naturally apply.

\section{REFERENCES}

1. Bush, A. J., \& Bush, R. P. (1986) Should advertisers use number-based copy in print advertisements? Journal of Consumer Marketing, 3, 71-79.

2. ChIlders, T. L., \& Houston, M. J. (1984) Conditions for a picture-superiority effect on consumer memory. Journal of Consumer Research, 11, 643-654.

3. Hirschmann, E. C. (1986) Effect of verbal and pictorial advertising stimuli on aesthetic, utilitarian and familiarity perceptions. Journal of Advertising, 15, 27-34.

4. McNurt, S. (1990) Loma Prieta earthquake October 17, 1989-Santa Cruz County, California. California Geology (California Department of Conservation), 43, 3-7.

5. SWINYARD, W. (1981) The interaction between comparative advertising and copy claim variation. Journal of Marketing Research, 18, 175-186.

Accepted July 9, 1991. 